OPEN ACCESS

Edited by:

Margaret Grogan,

Chapman University, United States

Reviewed by:

Rachel McNae,

University of Waikato, New Zealand

Teresa Wasonga,

Northern Illinois University,

United States

${ }^{*}$ Correspondence:

Paula A. Cordeiro

cordeiro@sandiego.edu

Specialty section: This article was submitted to Leadership in Education, a section of the journal

Frontiers in Education

Received: 16 October 2020 Accepted: 03 March 2021

Published: 12 April 2021

Citation:

Cordeiro PA, Gluckman M and Johnson A (2021) Responses to

COVID-19 From Non-State School

Leaders in Latin America,

Sub-Saharan Africa and, India: A Call

for Educational Equity.

Front. Educ. 6:618323.

doi: 10.3389/feduc.2021.618323

\section{Responses to COVID-19 From Non-State School Leaders in Latin America, Sub-Saharan Africa and, India: A Call for Educational Equity}

\author{
Paula A. Cordeiro ${ }^{1 *}$, Maxie Gluckman ${ }^{2}$ and Andy Johnson ${ }^{3}$ \\ ${ }^{1}$ Kroc School of Peace Studies, University of San Diego, San Diego, CA, United States, ${ }^{2}$ Education Studies, University of \\ California, San Diego, San Diego, CA, United States, ${ }^{3}$ Edify, San Diego, CA, United States
}

In early 2020, the rapid spread of the COVID-19 pandemic was an unprecedented shock to the global education system, resulting in most educational institutions closing their doors and turning to various forms of remote learning to ensure continuous education for their communities. Since the world has not experienced this scale of school closure before, the goal of this study was to explore what, if anything, non-state schools (NNSs) were doing to support remote learning that may help them to prepare for future events that curtail education. In May 2020, Edify, an international non-governmental organization (INGO) operating in eleven nations in Latin America (LATAM), Sub-Saharan Africa and India conducted a telephone survey with a stratified random sample of 388 school leaders. Since the extent learning had continued across contexts was relatively unknown, the survey aimed to inform the organization's current and future responses to the COVID19 pandemic and potential future educational interruptions. In addition to identifying the various uses of technology and possible innovations as to how non-state schools can respond when a crisis impacts their operating status, this paper describes three areas of concern expressed by the school leaders: (1) the health and safety of children and adults in their schools; (2) the various challenges of maintaining financial sustainability; and (3) the learning loss of students from the lack of preparedness for such a massive interruption in their school's normal operations.

Keywords: low-fee private schools, non-state schools, school leadership, blended learning, COVID 19 impacting schools

\section{INTRODUCTION}

The rapid spread of the COVID-19 pandemic resulted in an unprecedented shock to the global education system. This resulted in most educational institutions closing their doors and turning to various forms of remote learning. Since the world has not experienced this scale of school closure before, the goal of this study was to explore what schools in the Latin America (LATAM) region, Sub-Saharan Africa and India were doing to support remote learning in order to help one international Non-Governmental Organization (INGO) better assist their partner schools in preparing for possible future educational interruptions. The schools targeted in this study are what we refer to as Non-State Schools (NSSs). 


\section{BACKGROUND}

In order to understand the response by NNSs during school closures, we have organized the background literature into six sections. We begin by reviewing the types and numbers of NNSs found in low and middle-income nations. This is followed by a discussion of the role NSSs play in the Millennium and Sustainable Development Goals. Next, we discuss school leadership in low and middle-income countries (LICs and MICS) ${ }^{1}$, since understanding the context of leadership preparation is a key aspect of how schools are prepared to respond in emergencies. Then we discuss the roles of nongovernmental organizations (NGOs), and in particular, highlight the international NGO (INGO) that partners with the schools that were the focus of this study. The conclude with a brief overview of the contexts of the countries included in this study.

\section{The Context of Non-State Schools (NSSs)}

NSSs have a long history in low and middle-income countries. The phenomena of "Westerners" and "Western based" organizations building schools in "third-world nations" has been occurring for centuries. Various faith-based groups (e.g., Jesuits, Friends, Methodists) and colonial governments (e.g., France, the U.K., the Netherlands) founded private schools in what the World Bank today refers to as Low and Middle-Income countries (LICs and MICs) beginning in the seventeenth century, with some still in existence today (Jones, 2008; Beadie and Tolley, 2013). Many of these schools targeted connecting locals to a particular faith, while others were schools serving expatriates with relatively high tuition that was often not available to locals and, in some cases, host country nationals were not allowed to enroll.

Today there is great diversity in the types of NSSs found in these emerging nations. In addition to single, independent private schools, there are a growing number of for-profit companies investing in chains of private schools (e.g., Bridge International Academies, Omega Schools) as well as various secular and faith-based INGOs partnering with them in a variety of ways (e.g., Worldreader, Edify, Room to Read, Opportunity International).

There are over 1.5 million schools in LICs and MICs that receive little or no government support and their numbers are growing exponentially (Day Ashley et al., 2014; The Economist, 2015). In many countries, anywhere from $20 \%$ to $85 \%$ of all schools are NSSs (CapPlus, 2017). According to the UNESCO Institute for Statistics, $42 \%$ of pre-primary, $18 \%$ of primary, and $26 \%$ of secondary students globally are enrolled in nonstate schools. This sector includes a mixture of non-profit, for-profit, and faith-based organizations providing schooling and other education services (The Economist, 2015; UNESCO, 2018). While many are run by religious groups or non-profit organizations, the fastest growing group are small, low-fee private

\footnotetext{
${ }^{1}$ The World Bank divides the world's economies into four income groups: low, lower middle, upper middle, and high-income countries. They are abbreviated as: LICs, MICs, and HICs.
}

schools run by local entrepreneurs (Cordeiro and Spencer, 2015); some of these schools are secular while many are faith-based (Woden, 2014). These schools are alternatively referred to as: Affordable Private Schools (APSs), Low-Cost Private Schools (LCPSs), Low-Fee Private Schools (LFPSs), Budget Schools (primarily in India), Low Fee Faith-Inspired Schools (LFFISs) and Non-State Schools (NSSs). In this paper we use the term NSSs since the majority do not receive government support and for those that do, the support covers only a few aspects of operating a school (i.e., providing free textbooks). Additionally, in recent years the term NSSs is more frequently used in the literature.

In their seminal research about private schooling in LICs and MICs, Tooley and Dixon (2007) discovered that many countries had large numbers of non-state schools. They found that in many cases ministries of education did not recognize these schools and government offices often denied their existence. The emergence of large numbers of private schools at the turn of this century, whether faith-based or secular, is not surprising given that many public-school systems in low and middle-income nations did not have the resources to serve thousands of children who had previously not attended school who are now attending in order to meet the targets of the Millennium Development Goals (Cordeiro and Cunningham, 2012).

\section{The Millennium and Sustainable Development Goals (MDGs and SDGs)}

When the MDGs were enacted in 2000, Goal 2-achieving universal primary education-was targeted "to ensure that, by 2015, children everywhere, boys and girls alike, will be able to complete a full course in primary schooling" (UN Sustainable Development Goals, 2015).

Overall, substantial progress has been made with the numbers of primary schools increasing as well as an improved literacy rate and a narrowing of the gap in the literacy rate between men and women. However, in some nations few targets were achieved and "In countries affected by conflict, the proportion of out-of-school children increased from $30 \%$ in 1999 to $36 \%$ in 2012 " (UNESCO, 2015, p. 7).

In spite of some progress overall the MDGs were not met. Governments in low-income and middle-income nations faced huge challenges when they agreed to the MDGs. There were far too few public-school facilities available to accommodate the numbers of children who needed to be enrolled and most education ministries and district offices were severely understaffed. Additionally, few teacher training colleges had the resources and staff to prepare the numbers of teachers needed.

In 2016, the MDGs transitioned to the SDGs, and now nearly all nations in the world are included. There are a total of 17 goals with dozens of targets for each goal. The objective is that these new goals will be achieved by 2030. Goal 4 is to include "inclusive and equitable quality education" (UN, 2015). According to several Global Monitoring Reports, some progress was made on the education targets between 2015 and 2020; however, in late 2019 and during the first half of 2020, with the advent of school closures due to COVID-19, progress came to a grinding halt and some countries experienced regression. 


\section{School Leadership in LICs and MICs}

Numerous scholars recognize that school principals ${ }^{2}$ are not prepared well-enough for the tasks they have to accomplish (Mestry and Grobler, 2003; Donlevy, 2009). Yet many scholars argue that school leaders play a crucial role in school improvement, teacher morale and retention, and student learning (Ingersoll, 2001; Leithwood et al., 2004; Marzano and McNulty, 2005; Grissom and Harrington, 2010; Swaffield et al., 2013; Cetin et al., 2016). Fullan and Hargreaves (1991) maintain that leaders create cultures of learning and that those cultures positively affect student learning. Leithwood and Jantzi (2008) suggest that leaders empower the more effective teachers and that it is through them that their student learning is experienced. More recent research has shown that professional development for school leaders is key to their development and can result in improved student learning outcomes (Miller et al., 2016; Grissom et al., 2021).

While much has been written about the important role of school leaders in North America, Europe and Australia (e.g., Leithwood, Sergiovanni, Darling-Hammond, Cordeiro, and Cunningham); there is now a small but growing body of empirical research about the work of school leaders in LICs and MICs. A recent bibliometric analysis of the school leadership literature by Hallinger and Kulophas (2020) found that the geographic imbalance of researchers who are Anglo-AmericanEuropean focused is migrating toward other regions of the world. For example, a growing number of scholars outside US, European, Australian and New Zealand contexts are including MICs in their scholarship. At the same time, scholarship from the first two decades of this century (Lumby et al., 2008; Schleicher, 2012) has moved from being descriptive to including more empirical studies from a variety of contexts worldwide.

The preparation and professional development of school leaders has been strongest in Anglo-European-American contexts; however, nations such as Mexico and Peru have placed the importance of preparing and supporting school leadership on their policy agendas (Flessa et al., 2018; Mestry, 2020). According to Swaffield et al. (2013) the overall limited attention paid to leadership preparation and development is evident in LICs and MICs. In most of these nations, there are many untrained school leaders who do not have the necessary skills, knowledge, or attitudes to manage their schools effectively and efficiently (Otunga et al., 2008; Cordeiro and Brion, 2018). Finally, with a few notable exceptions (e.g., Oduro and MacBeath, 2003; Bush and Oduro, 2006; MacBeath et al., 2010; Moorosi and Bush, 2020) there is even less research on school leaders in Sub-Saharan Africa.

Similarly, there is a paucity of scholarship about leaders of private Faith-Inspired Schools (FISs), since most studies explore leadership in government (public) schools. There are a few important exceptions. In the 2014 special issue of Faith and International Affairs. Guest editor and World Bank adviser Quentin Wodon assembled seven research-based articles

\footnotetext{
${ }^{2}$ We use the terms Principal, Head Teacher, and Director interchangeably since those are typical terms used in the countries in this study. Sometimes the person in this position is also the school owner or proprietor.
}

focusing on FISs in Sub-Saharan Africa. Wodon maintains that "...there is a renewed and growing recognition that FISs have an important role to play in the efforts undertaken by Ghana [and other developing nations] to achieve the Millennium Development Goals" (p. 2). More recently several authors discuss the role of faith based low-fee private schools in Kenya and Haiti (Sivasubramaniam and Rider, 2017) and Ghana, Burkina Faso and Liberia (Cordeiro and Brion, 2018) in which they describe how many of the founders established their schools in order to make a difference for the future of their communities and nations. They refer to the task of leading schools as a type of "calling" that motivates them to undertake this work.

The majority of studies in education in LICs and MICs describe the work of teachers, and at times, principals of public schools; little appears in the research literature about school leaders in NNSs. Private schools are unique; especially private schools set up as social enterprises. Since the benefits of non-profit tax laws that countries like the US have are not typically found in low and middle-income nations, private schools are forced to incorporate as forprofit businesses. As a result, their structures are usually different from structures found in US independent schools. For example, unlike non-profit schools in North America or Europe, many of the countries in which these schools reside do not require them to have a board of directors nor in most cases do they receive any type of government funding. And, in most countries they are required to pay property taxes.

Some LICs and MICs in Central/South America, such as Peru (one of the countries included in this study), have begun providing training for school leaders. However, Peru is one of the exceptions and although there are nations with particular initiatives in certain regions (e.g., Argentina, Mexico, Brazil) it is not obligatory that school leaders in state or non-state schools meet particular standards in order to become school leaders (Flessa et al., 2017). However, LICs and MICs do have minimum requirements for teachers and the vast majority of school leaders have served as classroom teachers. In Africa in particular, there are many untrained principals who do not have the necessary skills, knowledge, or attitudes to manage their schools effectively and efficiently (Otunga et al., 2008). Africa is a complex continent because of its geography and sociopolitical issues. School leadership preparation and professional development as well as educational reform are often caught between the colonial legacy and the goals of donors, which is one of the reasons why leadership preparation is practically non-existent with South Africa being one exception on the continent (Eacott and Asuga, 2014). Africa is also unique because almost every country is a low-income country. Therefore, for an INGO working with thousands of schools in nations that have little opportunity for school leaders to develop professionally, such as the case with the NGO involved in this study, it is paramount for them to understand what is happening on the ground in schools. Clearly, during times of crisis such as during a pandemic, it becomes even more important to understand how INGOs can immediately work with school leaders in order to 
support their partner schools especially since few governments in LICs and MICs provide any systematic support or professional development to private school leaders.

\section{International Non-Governmental Organizations (INGOs) Working in Education}

The term NGO is interchangeable with other terms used around the world including third-sector, non-profit, voluntary, and civil society organizations. The word non-profit organization is typically used in the US while most other nations use the term NGO. An INGO is, in its broadest sense, any business or organization doing humanitarian work in at least two countries and is not a part of any government entity. Although they were in existence prior to the mid-1940s, it was the United Nations that introduced the concept of NGOs. The United Nations' Economic and Social Council defines an international NGO as "any international organization which is not established by a governmental entity or intergovernmental agreement" (UNESCO, 2016a).

NGOs tend to fall into two categories. Advocacy NGOs promote or defend specific causes and work to influence public policy either locally, nationally or internationally. A second type of NGO are those that are operational. These types design and implement development projects.

International NGOs range from secular organizations, such as Save the Children to religiously affiliated ones such as World Vision International. They may fund local NGOs, institutions and projects, and/or implement their own projects. INGOs can be found in many sectors (i.e., health, education, human rights, environmentalism). There are many INGOs working in the education sector with some partnering directly with schools (e.g., Opportunity International, IDP Rising) while others compliment or more indirectly support student learning (e.g., Aflatoun International, Room to Read). There is considerable overlap in these roles. The INGO that is the focus of this paper works directly with their partner schools with local staff frequently visiting schools to provide training and leadership coaching.

\section{Edify: An International Non-Governmental Organization (INGO)}

Edify is a faith-based INGO that falls into the category of being operational. In addition to providing micro-loans to schools, they offer trainings for school leaders and teachers. Headquartered in the US, Edify has numerous country offices recognized as local NGOs by the nations in which they work. It is divisionally organized, with the local country office making final decisions on what programs will be implemented in the various areas (e.g., micro-loans, faith formation, education) in which Edify works. Local Edify Education Specialists offer all schools intensive leadership development trainings covering the basics of managing a school and leading instruction to improve student learning. Additionally, Edify's Education Technology Officers serve as consultants and coaches as school use instructional technology.
The Central Services Office operates out of the US and supports the work of the country offices and provides strategic direction. Edify has a governing board composed of members from different sectors and areas of the world as well as local advisory boards and networks. This INGO partners with school "entrepreneurs who need access to training, capital and technology to grow their schools" (Edify, 2020), and works only with those schools that are self-identified as faith-based. Edify partners with over 6,000 schools in eleven countries (Burkina Faso, Dominican Republic, Ethiopia, Ghana, Guatemala, India, Liberia, Peru, Rwanda, Sierra Leone, and Uganda), and local country staff is key in supporting programs which local schools decide to utilize. The majority of the different trainings that Edify offers target school leaders through its theory of change: "if you build the capacity of school leaders, they in turn will hire and train effective teachers, thus creating strong and effective working environments needed for adults and children to teach and learn" (Edify, 2020). Edify's goal is to empower school leaders so they can drive their own learning.

This concept of empowerment shifts a deficit-orientation toward a more strength-oriented perception. Edify's mission and structure requires staff to continuously seek input by listening intently to the challenges faced by their multiple partners (e.g., schools, training partners, microfinance institutions). Edify staff often refer to listening to the needs identified by partner schools as: "walking alongside the schools and the school leaders."

\section{The Context of LICs and MICs in This Study}

The eleven countries included in this study are from three regions of the world: Latin America (Peru, the Dominican Republic, Guatemala); Sub-Saharan Africa (Burkina Faso, Ethiopia, Ghana, Liberia, Rwanda, Sierra Leone, Uganda) and India (the Northeast Region). Peru and India are the only nations in this group that the World Banks assigns as high-middle or low-middle countries, respectively. The remaining nations are categorized as lowincome (Serrajuddin and Hamadeh, 2020). A detailed discussion of the contexts of each of these nations is not possible here; however, understanding why some nations and or regions within nations are not yet deploying digital technologies is key to better understanding and promoting future policies and practices. According to a recent study by United National Children's Fund International Telecommunication Union (2020), more than twothirds of children and youth across the world do not have an internet connection at home. The differences in internet access between low/middle income nations and high-income ones are stark and this is further exacerbated by the urban-rural divide. Overall, interconnectivity for school-age children in sub-Saharan Africa is the lowest in the world with West and Central Africa being even lower than East and Southern Africa. Four of the nations in this study (Burkina Faso, Ghana, Liberia, Sierra Leone) are located in West Africa, while three nations (Uganda, Ethiopia, Rwanda) are in East Africa; therefore, as we created the research questions for this study, we hypothesized that in LICs we would find fewer schools using digital technology as part of their remote learning strategy. 


\section{Theoretical Framework for the Study}

In promoting the preparation of school leaders, Normore and Lahera (2018) maintain that we must examine various practices that support the development of leaders committed to social justice, equity, diversity and access. One aspect of social justice is how school leaders respond to the inequities in digital access and digital equity. Digital equity includes equitable access and the "effective use of technology for teaching and learning, access to content that is of high quality and culturally relevant" (Judge et al., 2004, p. 383). Recent literature in a high-income country such as the US has highlighted the gap in digital access during the COVID-19 pandemic. Teachers working in high-poverty schools were more likely to report that their students lacked internet access at home (Stelitano et al., 2020). With the multitude of challenges faced by school leaders in LICs and MICs, the NGO involved in this study was interested in exploring how the pandemic has impacted students learning remotely, and how they could better support their partner school leaders in addressing issues of equity.

\section{THE RESEARCH STUDY}

Given the large numbers of non-state schools in the LATAM, Sub-Saharan and Indian contexts, we were interested in investigating how schools based on tuition rather than government support have responded to children's learning needs during the pandemic. We were also interested in how school leaders described the key challenges they have faced. Thus, we analyzed data used for an original report commissioned by Edify. The full report and the subsequent country specific reports had three purposes. First, was to assist Edify staff in understanding what was happening with the students enrolled in these NSSs during school closures due to the COVID-19 pandemic and how to best support these schools. Secondly, the purpose of the country specific reports was to help school leaders better understand what was occurring in schools in their own countries with context specific recommendations. Finally, the NGO wanted to better understand the financial challenges of the schools during the pandemic. As a result of the survey's findings Edify was able to appeal to donors and a COVID-19 Relief Fund was created.

For the present study, we utilized Edify's original data set and investigated the following research questions: (1) How, if at all, did non-state schools respond to student learning needs during school closures due to COVID-19?; (2) What were the major concerns of school leaders during school closures?; and (3) What educational innovations, if any, were non-state schools utilizing to address student learning needs during school closure?

\section{METHODS}

In order to address these three research questions, we reviewed data collected by Edify through a twelve-question survey with a sample of 388 schools across 11 nations in Africa, Latin America, and India, in late May, 2020. This sample included Edify "Client" schools which means they are actively connected to this NGO, and "Core" schools- a subset of Client schools which Edify supports more intensively for a period of 3 years. Because this NGO works more intensively with Core schools, they were particularly interested in finding out if Core schools were doing anything differently from Client schools during the pandemic. However, for the current study, we solely present the data on Client schools in order to compare schools with similar levels of support across all nations.

To prepare for survey administration, two team members from each country were recruited and trained to serve as data collectors. All data collectors were local NGO staff who speak the many local languages and dialects in which the survey was administered. In May 2020, all data collectors participated in an online training session, led by two of the researchers, on the what, how, and why of the data collection protocol. Slight modifications to the survey instrument were made based on feedback during the training session to ensure question clarity and ease of survey use.

\section{Data Collection}

Following the training, each country data collection team was provided with a virtual set of resources including: 1. Access to the survey created on Google Forms; 2. A list of 100 "Client" schools in the country that received Edify support in the past year and have at least 100 enrolled students, with the school's accompanying contact and geo-localization information; 3. An additional list of 10 "Core" schools each for the Dominican Republic, Ghana, Guatemala, Peru, and Rwanda. These countries had, for at least 1 year, been implementing the "Core School" Edify model; and 4. A data collector script to guide them through introducing the study, requesting permission to proceed, and sample follow-up questions to probe for additional information as needed. The school lists presented to each country's data collection team were created utilizing a stratified, random sampling technique drawing from the organizational database for each country.

Over the course of 1 week in late May 2020, the data collectors followed a series of steps. They began by reviewing the list of 100 schools and noted whether they were located in an urban, peri-urban, or rural context. This step was intended to ensure the representativeness of schools that may have had more ready access to resources and technology with those that do not. Secondly, data collectors administered the survey by beginning at the top of the list, until 30 schools (ten urban, ten peri-urban, and ten rural) were represented. Due to the brief timeline for data collection, data collectors were told to proceed to the next school in the list, in order, if they were not able to contact either the school proprietor or principal and receive permission for an interview. Data collectors were then asked to record the name and respondent's position on a Google Form. Although the survey questions were written in English, data collectors conducted the survey with school leaders in Spanish, French, and local languages based on the comfort level of those being interviewed and then noted the participant responses in English. As such, the quotes included have been presented in standard English for ease of the reader and for consistency. Next, if applicable, data collectors administered the survey to their ten "Core" schools. This was followed by translating the original 
data into English and inputting data either in real-time or after the conversations-depending upon internet availability-to the Google Form.

The survey contained demographic information and four questions with predefined dropdown options. In the quantitative section, participants were asked if the school was providing education to students during school closures. If they were not doing so, the data collector was instructed to skip to the final question; if the answer was affirmative, the data collector continued to the next question. The three subsequent quantitative questions sought to determine who was providing education for students during school closures, the status of payment to teachers, and what the school was doing to support children and families remotely. The options provided were validated by country staff during the data collector training; an "other" category was added to ensure that all activities or interventions would be captured. Data collectors were asked to record any feedback on what schools were doing to support learning or any additional details that they found helpful from the conversation in a subsequent open-ended response question, particularly if respondents selected the "other" option. The final question was qualitative and participants were asked to reflect on what they were most concerned about in terms of returning to school post-closures.

\section{Data Analysis}

Using Excel, the quantitative data provided by Edify was cleansed and analyzed by the authors in order to check for errors. During this multi-stage review by a team of three, certain data inconsistencies were recognized that required the team to discuss and create inclusion and exclusion criteria for data as well as to re-code certain data collected.

One data inconsistency that emerged during cleaning and initial analysis was in regard to the question of who was providing education during school closures. The options provided were "school proprietor," "head teacher/principal/director," "some of the school's teachers," and "all of the school's teachers" and those surveyed were allowed to choose all that applied. By doing so, some participants selected "some of the school's teachers" and "all of the school's teachers" which the data analysis team re-coded to "all of the school's teachers" to correct for duplicate options that did not appear logical. In addition, a new code category was created called "Operating without teachers" which was coded if the participant noted that only the "school proprietor" and/or the "head teacher/principal/director" were providing education during school closures. This code was created as a way of analyzing the prevalence of schools in each country that were unable to employ any teachers during closures.

The qualitative data was inputted into Dedoose qualitative coding software and analyzed for major emerging themes. Drawing upon initial analyses, numerous presentations were delivered from May 28-June 16, 2020 to the NGO's Country Directors, the Education Team, an Education Task Force, donors, and the Senior Leadership Team. Feedback and suggestions for short, medium, and long-term actions were solicited. The findings include an overview of the data, themes that emerged, regional and country-specific details, and related recommendations for non-state schools and educational leaders to use in developing financial sustainability, create strategies for ensuring continuous and quality learning during schooling interruptions, and identifying health and safety considerations for schools returning to in-person instruction post-pandemic.

In the original data set there were ten countries and 357 schools, with 308 Client schools and 49 Core schools. For the current study, data is only presented on Client schools, hereafter referred to as "schools," by country and by region-Latin America, Africa, and Northeast India. Thus, for the purposes of this paper, the data from 308 schools in ten countries are presented.

\section{Limitations}

It is important to note that this study has numerous limitations. First, the study only captured the status of what schools were doing to support learning during 1 week in May, 2020. Given that some countries had closed schools in March while others did so in April, the time for schools to respond to school closures varied considerably from nation to nation; thus, some school leaders may not have fully grasped that it could be months before schools reopened so they had not yet implemented remote learning activities. The survey was administered by 22 data collectors, and although they received some training in how to conduct the survey, there was little time to practice during that training. There was also the added issue of language translation since within some countries multiple languages are spoken and the data collectors were required to translate to English. Another limitation was the small sample size from each country. The data presented here only includes 30 NSSs per nation. Finally, all schools in this study are faith-based, and they may not be representative of all NNSs in a particular nation.

\section{FINDINGS}

The findings are divided in three sections. We begin with how schools addressed how to support students as they continued learning during the closure of all schools. This is followed by identifying three major areas of concerns identified by school leaders as they awaited the reopening of schools. The final section describes some of the innovative ways principals, school owners and teachers provided an education in spite of the many challenges they faced.

\section{Schools Offering Educational Support During School Closures}

Across the ten-country sample, $75 \%$ of schools $(n=232)$ reported providing educational support during school closures. Regionally there were considerable differences, with $100 \%$ of schools $(n=$ 91) in Latin America offering education programming, while only $80 \%(n=24)$ of schools in the Northeast of India offered educational support to students and families, and 63\% $(n=$ $117)$ in Africa. Wide differentials can be seen among the African nations ranging from $100 \%$ of Ethiopian schools providing education to only $29 \%$ of Ghanaian schools (Table 1).

When examining schools by geographic area, Ethiopia, Guatemala, Peru, and the Dominican Republic did not reflect any differences between those in urban, peri-urban, or rural areas 
TABLE 1 | Schools offering educational support during school closures $(n=308)$.

\begin{tabular}{lc}
\hline & Percent $(\boldsymbol{n})$ \\
\hline Burkina Faso & $55 \%(n=17)$ \\
Ethiopia & $100 \%(n=32)$ \\
Liberia & $78 \%(n=25)$ \\
Uganda & $77 \%(n=23)$ \\
Rwanda & $35 \%(n=11)$ \\
Ghana & $29 \%(n=9)$ \\
Guatemala & $100 \%(n=29)$ \\
Peru & $100 \%(n=30)$ \\
Dominican Republic & $100 \%(n=32)$ \\
North East India & $80 \%(n=24)$ \\
Total & $75 \%(n=232)$ \\
\hline
\end{tabular}

TABLE 2 | Schools offering educational support during school closures by geographic area.

\begin{tabular}{lccc}
\hline & $\begin{array}{c}\text { Urban } \\
\text { percent } \\
(\boldsymbol{n}=\mathbf{1 0 3})\end{array}$ & $\begin{array}{c}\text { Peri-Urban } \\
\text { percent } \\
(\boldsymbol{n}=\mathbf{1 0 7})\end{array}$ & $\begin{array}{c}\text { Rural } \\
\text { percent } \\
\mathbf{( n = 9 8 )}\end{array}$ \\
\hline Burkina Faso & $55 \%(n=6)$ & $55 \%(n=6)$ & $56 \%(n=5)$ \\
Ethiopia & $100 \%(n=12)$ & $100 \%(n=10)$ & $100 \%(n=10)$ \\
Liberia & $80 \%(n=8)$ & $92 \%(n=11)$ & $60 \%(n=6)$ \\
Uganda & $75 \%(n=6)$ & $67 \%(n=6)$ & $85 \%(n=11)$ \\
Rwanda & $40 \%(n=4)$ & $45 \%(n=5)$ & $20 \%(n=2)$ \\
Ghana & $30 \%(n=3)$ & $30 \%(n=3)$ & $27 \%(n=3)$ \\
Guatemala & $100 \%(n=10)$ & $100 \%(n=10)$ & $100 \%(n=9)$ \\
Peru & $100 \%(n=10)$ & $100 \%(n=10)$ & $100 \%(n=10)$ \\
Dominican Republic & $100 \%(n=12)$ & $100 \%(n=15)$ & $100 \%(n=5)$ \\
North East India & $90 \%(n=9)$ & $78 \%(n=7)$ & $73 \%(n=8)$ \\
\hline
\end{tabular}

with $100 \%$ of schools in each category offering education during school closures. Ghana and Burkina Faso reflected the same for urban and peri-urban, but with a slight difference in rural schools. Liberia, Northeast India, and Rwanda reflected lower percentages for the operation of rural schools, whereas Uganda reflected a higher percentage of operation in rural areas (Table 2).

\section{Teacher Work and Pay Status}

Two survey questions asked about teacher work status followed by pay status. Among those schools that continued to operate during closures, teachers' work and pay statuses reflect a wide diversity across the ten nations.

Across all 10 countries, $44 \%$ of schools $(n=101)$ said that all teachers were still teaching, $46 \%(n=106)$ said that some teachers were still teaching, and only $10 \%(n=24)$ were providing education during school closures but without teachers, meaning that only the proprietor and/or principal were working (Table 3).

But the fact teachers are working does not necessarily mean they are receiving full or partial salary, nor does it mean they are being paid on time; this data is reviewed in the following section. The Dominican Republic and Guatemala represent
TABLE 3 | Teacher work status $(n=232)$.

\begin{tabular}{lccc}
\hline & $\begin{array}{c}\text { Operating } \\
\text { without teachers } \\
\text { (proprietor/principal } \\
\text { only) } \\
\%(\boldsymbol{n})\end{array}$ & $\begin{array}{c}\text { Some teachers } \\
\text { still teaching } \\
\%(\boldsymbol{n})\end{array}$ & $\begin{array}{c}\text { All teachers still } \\
\text { teaching } \\
\%(\boldsymbol{n})\end{array}$ \\
\hline Burkina Faso & $18 \%(n=3)$ & $76 \%(n=13)$ & $6 \%(n=1)$ \\
Ethiopia & $34 \%(n=11)$ & $28 \%(n=9)$ & $38 \%(n=12)$ \\
Liberia & $4 \%(n=1)$ & $36 \%(n=9)$ & $60 \%(n=15)$ \\
Uganda & $0 \%(n=0)$ & $96 \%(n=22)$ & $0 \%(n=0)$ \\
Rwanda & $18 \%(n=2)$ & $55 \%(n=6)$ & $27 \%(n=3)$ \\
Ghana & $0 \%(n=0)$ & $78 \%(n=7)$ & $22 \%(n=2)$ \\
Guatemala & $14 \%(n=4)$ & $3 \%(n=1)$ & $83 \%(n=24)$ \\
Peru & $3 \%(n=1)$ & $80 \%(n=24)$ & $17 \%(n=5)$ \\
Dominican & $3 \%(n=1)$ & $6 \%(n=2)$ & $91 \%(n=29)$ \\
Republic & & & \\
North East & $4 \%(n=1)$ & $54 \%(n=13)$ & $42 \%(n=10)$ \\
India & & & \\
Total & $10 \%(n=24)$ & $46 \%(n=106)$ & $44 \%(n=101)$ \\
\hline
\end{tabular}

the countries with the highest number of schools that were continuing to employ all teachers at $91 \%(n=29)$ and $83 \%$ $(n=24)$, respectively. Uganda is the only country with no schools indicating that all their teachers were still teaching but reflects the highest percentage of schools with some teachers still teaching $(96 \%, n=22)$. In Ethiopia, 34\% of schools were operating without teachers $(n=11)$, followed by Burkina Faso (18\%, $n=3)$, and Rwanda (18\%, $n=2)$ (Table 3). Overall, the status of operating without teachers was much more common in African countries (15\%) when compared to Latin American (7\%) and Northeast Indian schools (4\%); however, Ghana and Uganda were the only African countries that did not have any schools report that they were operating without some teacher support.

\section{Teacher Payment Status}

Schools that were in active operation were asked to indicate which of the following best represented the payment status of their teachers: teachers being fully paid, some teachers being paid, teachers working for deferred payment, and/or teachers being unpaid. As it was possible that schools had multiple scenarios of payment, they were able to choose all that applied, and therefore, the totals in each country do not add up to $100 \%$.

Across all schools surveyed that were offering education, only $29 \%(n=68)$ of school leaders said their schools were fully paying teachers, with teachers working for deferred payment as being the second most likely scenario at $28 \%(n=66)$, followed by teachers being unpaid at $16 \%(n=37)$, and teachers working for deferred payment at $12 \%(n=27)$ (Table 4$)$.

The Dominican Republic and Guatemala had the highest percentages of schools fully paying their teachers at $75 \%(n=24)$ and $69 \%(n=20)$, respectively, followed by Ethiopia at $44 \%$ ( $n$ $=14)$, and Liberia at 20\% $(n=5)$. Northeast India, Ghana, and Uganda had no schools indicating they were fully paying their teachers with teachers working for deferred payment or being unpaid the most common scenarios. Rwandan schools were by 
TABLE 4 | Teacher payment status $(n=232)$.

\begin{tabular}{lcccc}
\hline & $\begin{array}{c}\text { Teachers fully } \\
\text { paid }\end{array}$ & $\begin{array}{c}\text { Some teachers } \\
\text { paid }\end{array}$ & $\begin{array}{c}\text { Receiving } \\
\text { deferred } \\
\text { payment }\end{array}$ & $\begin{array}{c}\text { Teachers } \\
\text { unpaid }\end{array}$ \\
\hline Burkina Faso & $6 \%(n=1)$ & $24 \%(n=4)$ & $6 \%(n=1)$ & $12 \%(n=2)$ \\
Ethiopia & $44 \%(n=14)$ & $9 \%(n=3)$ & $6 \%(n=2)$ & $3 \%(n=1)$ \\
Liberia & $20 \%(n=5)$ & $32 \%(n=8)$ & $32 \%(n=8)$ & $16 \%(n=4)$ \\
Uganda & $0 \%(n=0)$ & $0 \%(n=0)$ & $48 \%(n=11)$ & $61 \%(n=14)$ \\
Rwanda & $9 \%(n=1)$ & $0 \%(n=0)$ & $82 \%(n=9)$ & $18 \%(n=2)$ \\
Ghana & $0 \%(n=0)$ & $0 \%(n=0)$ & $67 \%(n=6)$ & $0 \%(n=0)$ \\
Guatemala & $69 \%(n=20)$ & $7 \%(n=2)$ & $10 \%(n=3)$ & $0 \%(n=0)$ \\
Peru & $10 \%(n=3)$ & $30 \%(n=9)$ & $53 \%(n=16)$ & $17 \%(n=5)$ \\
Dominican & $75 \%(n=24)$ & $0 \%(n=0)$ & $3 \%(n=1)$ & $0 \%(n=0)$ \\
Republic & & & & \\
North East & $0 \%(n=0)$ & $4 \%(n=1)$ & $38 \%(n=9)$ & $38 \%(n=9)$ \\
India & & & & \\
Total & $29 \%(n=68)$ & $12 \%(n=27)$ & $28 \%(n=66)$ & $16 \%(n=37)$ \\
\hline
\end{tabular}

TABLE 5 | Teacher payment status by geographic area.

\begin{tabular}{|c|c|c|c|c|}
\hline & $\begin{array}{c}\text { Africa } \\
\%(n=96)\end{array}$ & $\begin{array}{l}\text { Latin America } \\
\quad \%(n=83)\end{array}$ & $\begin{array}{l}\text { North East } \\
\quad \text { India } \\
\%(n=19)\end{array}$ & $\begin{array}{c}\text { Total } \\
\%(n=40)\end{array}$ \\
\hline $\begin{array}{l}\text { Teachers fully } \\
\text { paid }\end{array}$ & $18 \%(n=21)$ & $52 \%(n=47)$ & $0 \%(n=0)$ & $29 \%(n=12)$ \\
\hline $\begin{array}{l}\text { Some } \\
\text { teachers paid }\end{array}$ & $13 \%(n=15)$ & $12 \%(n=11)$ & $4 \%(n=1)$ & $12 \%(n=9)$ \\
\hline $\begin{array}{l}\text { Receiving } \\
\text { deferred } \\
\text { payment }\end{array}$ & $32 \%(n=37)$ & $22 \%(n=20)$ & $38 \%(n=9)$ & $28 \%(n=16)$ \\
\hline $\begin{array}{l}\text { Teachers } \\
\text { unpaid }\end{array}$ & $20 \%(n=23)$ & $5 \%(n=5)$ & $38 \%(n=9)$ & $16 \%(n=3)$ \\
\hline
\end{tabular}

far the most common to have their teachers working for deferred payment $(82 \%, n=9)$, followed by Ghana $(67 \%, n=6)$, and Peru $(53 \%, n=16)$.

Teacher payment status differed greatly across geographic regions, with Latin American schools representing the highest percentage paying their teachers in full $(52 \%, n=47)$, followed by Africa at $18 \%(n=21)$ (Table 5$)$.

No schools in Northeast India indicated their teachers were being fully paid, with the most common scenario being that teachers were working for free $(38 \%, n=9)$ or were working for deferred compensation $(38 \%, n=9)$. Working for deferred payment was slightly less likely in African countries (32\%, $n=$ 37 ) and least likely in Latin American schools (22\%, $n=20)$. The situation where only some teachers are paid and others are not was most common in Africa (13\%, $n=15)$, followed by Latin America $(12 \%, n=11)$, and Northeast India $(4 \%, n=1)$. Africa and Latin America did also have some schools that had teachers working without pay, $20 \%(n=23)$ and $5 \%(n=5)$, respectively, but to a much lesser degree than Northeast India. As this data reflects, there was a wide array of payment patterns for teachers when analyzed by country and region-data which could inform appropriate school financing related interventions.

\section{Types of Educational Support Provided}

Participants who indicated that their school was operating during closures were asked to describe the types of educational support they were offering. During the survey, they were asked to choose all that apply from six educational support options: Calling families and talking to parents and children every 1-2 weeks; providing instruction and assignments on paper; teaching through messaging apps such as WhatsApp; teaching over video or audio conferencing; using a learning management system (LMS) such as Google Classroom; and/or following up on student engagement with educational TV and radio. Participants were also allowed to select "other" as relevant and provide an open response to other educational supports they were offering.

\section{Prevalence of All Types of Support}

Across all 232 schools in the sample offering educational services during school closures, 35\% indicated that they provided some sort of support through technology and 53\% through paper methods (Figure 1). Technologies utilized included use of messaging apps, video or audio conferencing, and/or LMS. This looked considerably different across regions, with Latin American schools primarily relying on technology (62\%) over paper (37\%), while Africa and NE India trended toward the other direction (61\% paper vs. $15 \%$ technology and $79 \%$ paper vs. $32 \%$ technology, respectively) (Table 6). In particular, $100 \%$ of Liberian schools indicated they provided instructions and assignments on paper, followed by $91 \%$ in Ethiopia, and $79 \%$ in NE India (Table 7).

With respect to technology use, phone messaging apps, such as WhatsApp and Telegram, were the most commonly referenced tool, employed by $63 \%$ of all schools operating during school closures (Latin America 92\%, NE India 79\%, Africa 38\%), followed by teaching over video/audio conferencing at $25 \%$ (Latin America 58\%, NE India 17\%, Africa 2\%), with followup on students' engagement with educational TV/Radio at $23 \%$ (Africa 26\%, Latin America 25\%, NE India 0\%) (Tables 6, 7).

Follow-up after TV/Radio programming was a particularly prevalent dynamic in Uganda at $83 \%(n=19)$ of schools, $55 \%$ $(n=6)$ in Rwanda, and $47 \%(n=14)$ in Peru. Teaching over video/audio conferencing and using a LMS was primarily employed in Latin America (58\% and 36\%, respectively). Video/audio conferencing was employed to a smaller degree in $17 \%(n=4)$ of schools in NE India and $4 \%$ or less of schools in Ghana and Uganda. In Latin America, nearly all of the Peruvian schools were teaching over video/audio conferencing $(97 \%, n=$ $29)$, followed by Guatemala $(55 \%, n=16)$, and to a lesser extent in the Dominican Republic $(25 \%, n=8)$. Guatemala reflected an overwhelming use of LMSs in the sample $(52 \%, n=15)$, followed by Peru $(40 \%, n=12)$, and Rwanda $(18 \%, n=2)$ (Table 7$)$.

The option of calling families and talking to parents or children at least every week or two was a commonly selected option amongst all schools and regions at $49 \%$ of the overall sample, and present in 50\%, 49\%, and 38\% of schools in Latin America, Africa, and NE India, respectively. In particular $96 \%$ of schools in Uganda selected this option and 73\% in Peru (Table 7). However, more information is needed to understand what they 


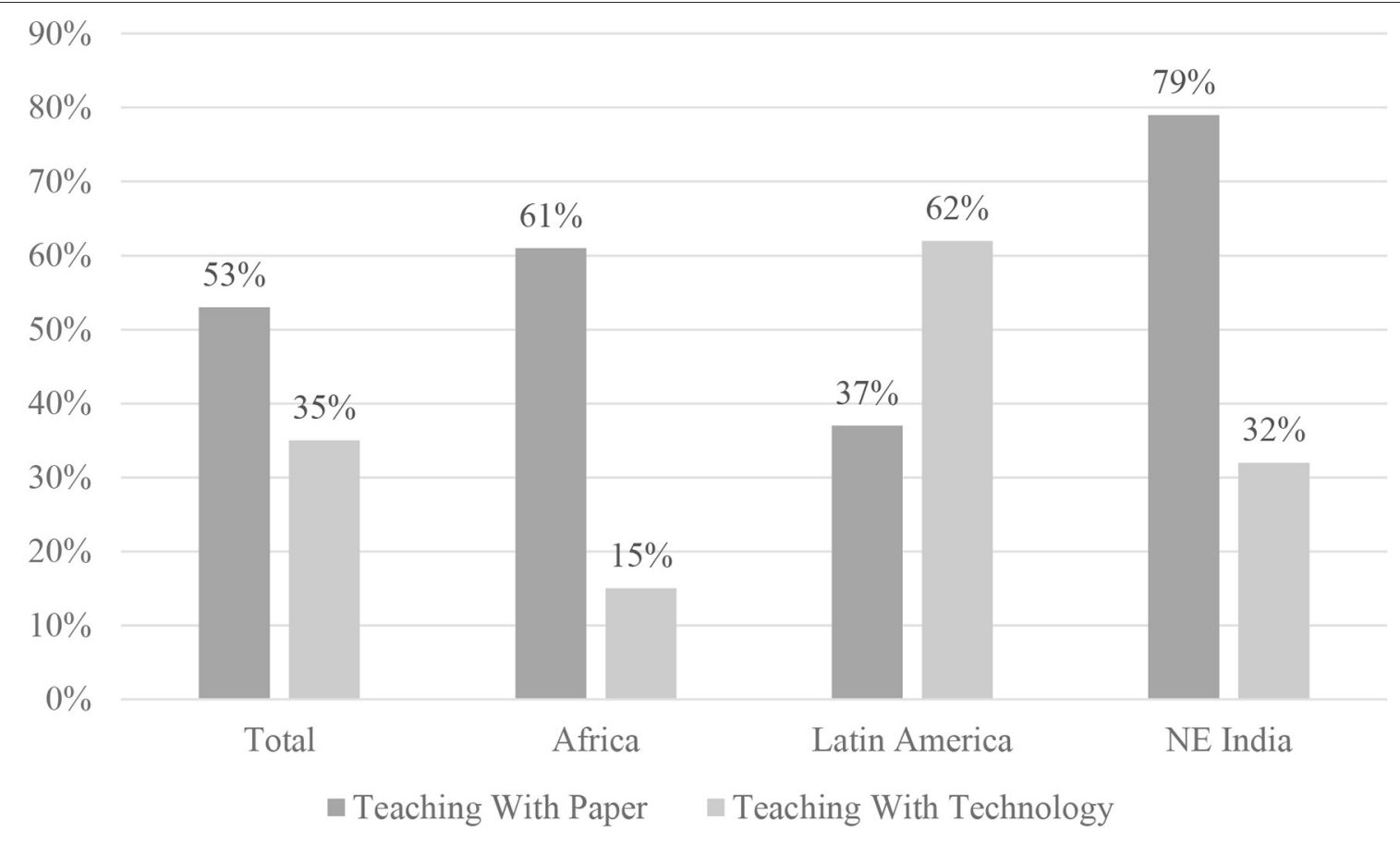

FIGURE 1 | Use of paper and technology (Edify Education Task Force, 2020).

TABLE 6 | Types of educational support by geographic area.

\begin{tabular}{|c|c|c|c|c|}
\hline & Africa & $\begin{array}{c}\text { Latin } \\
\text { America }\end{array}$ & $\begin{array}{c}\text { North East } \\
\text { India }\end{array}$ & Total \\
\hline $\begin{array}{l}\text { Calling families and } \\
\text { talking to parents } \\
\text { and children }\end{array}$ & $50 \%$ & $49 \%$ & $38 \%$ & $49 \%$ \\
\hline $\begin{array}{l}\text { Instruction and } \\
\text { assignments on } \\
\text { paper }\end{array}$ & $61 \%$ & $37 \%$ & $79 \%$ & $53 \%$ \\
\hline $\begin{array}{l}\text { Teaching through } \\
\text { messaging apps }\end{array}$ & $38 \%$ & $92 \%$ & $79 \%$ & $63 \%$ \\
\hline $\begin{array}{l}\text { Teaching over } \\
\text { video/audio } \\
\text { conferencing }\end{array}$ & $2 \%$ & $58 \%$ & $17 \%$ & $25 \%$ \\
\hline $\begin{array}{l}\text { Using a learning } \\
\text { management } \\
\text { system }\end{array}$ & $5 \%$ & $36 \%$ & $0 \%$ & $17 \%$ \\
\hline $\begin{array}{l}\text { Following up on } \\
\text { student engagement } \\
\text { with educational } \\
\text { TV/radio }\end{array}$ & $26 \%$ & $25 \%$ & $0 \%$ & $23 \%$ \\
\hline
\end{tabular}

were doing during those phone calls to determine that the calls would be considered strictly educational support.

\section{SCHOOL LEADERS CONCERNS}

The final open-ended question in the survey asked participants to address concerns they held about reopening schools. Responses were coded into three major categories: financial sustainability, health and safety, and student learning loss.

\section{Financial Sustainability}

A major concern expressed by school leaders was the fiscal sustainability of their schools. There was a high level of concern that parents were having difficulty in paying school fees which would lead to school proprietors having difficulty paying teachers, purchasing needed materials, paying rent, and repaying outstanding loans.

\section{Recovering School Fees: "How Will We Be Able to Pay Teachers?"}

When the survey was conducted, most schools expressed concerns about not being able to "recover fees" that were already owed before the schools closed, as well as fees owed during the months of closure. Many schools expressed fears that parents who were "informal workers" would not be able to pay for the remainder of the previous term, never mind for the upcoming term. As one Ghanaian leader noted, "some parents have shared that they would rather keep their children receiving remote instruction in exchange for lower tuition cost." Numerous references were made to financial sustainability. One Guatemalan proprietor commented, "Our school has been struggling under normal conditions before this crisis, and it may not continue because we do not have basic materials and funding." The following comment was typical of many others, "We need financial sustainability. Currently, schools are closed. No classes. No fees. No income. If this situation continues any longer, many of the schools, including us, will not be able to survive." The 
TABLE 7 | Educational supports provided.

\begin{tabular}{|c|c|c|c|c|c|c|}
\hline & $\begin{array}{l}\text { Calling families } \\
\text { and talking to } \\
\text { parents and } \\
\text { children }\end{array}$ & $\begin{array}{l}\text { Instruction and } \\
\text { assignments on } \\
\text { paper }\end{array}$ & $\begin{array}{l}\text { Teaching through } \\
\text { messaging apps }\end{array}$ & $\begin{array}{l}\text { Teaching over } \\
\text { video/audio } \\
\text { conferencing }\end{array}$ & $\begin{array}{l}\text { Using a learning } \\
\text { management } \\
\text { system }\end{array}$ & $\begin{array}{l}\text { Following up on } \\
\text { student } \\
\text { engagement with } \\
\text { TV/radio }\end{array}$ \\
\hline Burkina Faso & $53 \%$ & $53 \%$ & $0 \%$ & $0 \%$ & $0 \%$ & $24 \%$ \\
\hline Ethiopia & $31 \%$ & $91 \%$ & $50 \%$ & $3 \%$ & $9 \%$ & $0 \%$ \\
\hline Liberia & $52 \%$ & $100 \%$ & $4 \%$ & $0 \%$ & $0 \%$ & $4 \%$ \\
\hline Uganda & $96 \%$ & $17 \%$ & $48 \%$ & $4 \%$ & $4 \%$ & $83 \%$ \\
\hline Rwanda & $27 \%$ & $0 \%$ & $82 \%$ & $0 \%$ & $18 \%$ & $55 \%$ \\
\hline Ghana & $22 \%$ & $44 \%$ & $78 \%$ & $0 \%$ & $0 \%$ & $0 \%$ \\
\hline Guatemala & $52 \%$ & $52 \%$ & $93 \%$ & $55 \%$ & $52 \%$ & $31 \%$ \\
\hline Peru & $73 \%$ & $37 \%$ & $83 \%$ & $97 \%$ & $40 \%$ & $47 \%$ \\
\hline Dominican Republic & $20 \%$ & $20 \%$ & $100 \%$ & $20 \%$ & $15 \%$ & $0 \%$ \\
\hline Northeast India & $38 \%$ & $79 \%$ & $79 \%$ & $17 \%$ & $0 \%$ & $0 \%$ \\
\hline Total & $49 \%$ & $53 \%$ & $63 \%$ & $25 \%$ & $17 \%$ & $23 \%$ \\
\hline
\end{tabular}

concerns of school leaders in NSSs regarding school fees may further be exacerbated by the uncertain timelines for school re-openings in many of the countries surveyed.

\section{Declining Enrollments: "We Need to Get All Students to Come Back"}

The majority of school leaders expressed concerns that they would have a considerable decline in enrollment once schools re-open as families might go to "...to a public school or a less expensive private one.” While some schools had been offering discounts (upwards of $30 \%$ ), this had resulted in variable success. Some school leaders reported that parents could not afford the school fee even with a $40 \%$ discount. Others expressed that "parents expect discounts on school fees in order to continue for the next school year," but lamented that in many cases, "this would make it impossible for the school to continue growing."

One Peruvian proprietor commented, "Some parents prefer to lose the school year rather than having to pay for a nonface-to-face service. If social distancing continues, the school will probably face a great loss of students." A few schools reported already having been informed that students were leaving, "We have five students who have left the school." Other proprietors expected lower enrollment when schools reopened, as many believed children would simply "drop out" of school. Several commented, "We are in a rural region, if this continues, the children will go to the fields to help their parents and not return to school." Another commented, "Many children may stop schooling forever as parents may fear to send them back to school again using disease and economic status as an excuse." These examples illustrate the potential short and long-term implications of COVID-19 on NSS enrollments and educational continuity for large groups of learners.

\section{Paying Teachers: "...Raising Chickens..."}

School leaders were worried that their enrollments would drop; thus, revenue would decrease, and in turn, result in an inability to pay teachers. In many cases, teachers were only partially paid while schools were closed or not paid at all; thus, they were at the time of the survey owed back wages. As one school leader noted "I am also concerned about how I will pay my teachers when I am only getting 50\% fees since February 2020.” Another stated, "I have paid teachers' salaries until March 2020, but not in April and May. I will have to pay them when we reopen."

Proprietors expressed concerns for these salary arrears For example, a Liberian school owner noted, "Since we have not received any school fees since March, I have no income and no funding for teachers' salaries. Also, I have outstanding loans I need to pay. Hence, since lockdown, my husband and I started raising chickens-about 400 , which are now about $1 \mathrm{~kg}$ in weight. When I am able to sell them, I should be able to pay my staff at least part of their salary." This example shows the creative strategies proprietors were employing to be able to financially support their teachers.

\section{Losing Teachers: "We May Lose Most of Our Good Teachers"}

Proprietors noted that salary arrears might lead to losing teachers as it is "difficult on their side to go without pay for a long period. We may lose most of our good teachers either to other schools or sectors, which may be a challenge when schools reopen." Another school leader commented, "With a population of 30 teachers, we could not afford to pay all their salaries as normal. We think this may affect the teachers' morale when we plan to re-open in September. Also, the majority of our staff comes from foreign countries, and they went home before lockdown; therefore, it may be hard for them to return with the border closures for foreigners and a quarantine of 14 days for returning residents." The concerns regarding non-receipt of school fees, inability to pay teachers, and the potential of losing good teachers reflect interconnected concerns, many of which were shared by school leaders. 


\section{Loans: "How Can I Free Myself From the Bank?"}

In addition to concerns for paying staff, school leaders expressed deep concern about not being able to repay their current loans-both personal and school related. Some commented that their "payment is far overdue," questioning how they might "raise funds to pay the loan" or "settle with the bank." Concerns over loans also carried over into personal finances as one Ugandan school leader commented, "My personal debt or liability is rising as I have borrowed for my teachers' March salary. If the school does not reopen soon and we do not get school fees from students, how will I pay off my personal loans?"

Some proprietors contemplated applying for new loans in order to pay teachers, but applying for these loans was a challenge. One school leader in Northeast India commented, "Our application for a loan to pay our teachers at our partner bank was turned down. We are worried about how our teachers will stay motivated when we cannot pay them until school reopens in September." A few reported that their government had said loans would be made available to private schools, yet "It has not yet happened." Several school leaders reported that they "... have been able to continue paying teachers thanks to a state loan" they applied for. However, according to their economic projections, this support would not be enough to start a new school year. As these examples reflect, the pressure to pay back loans, the uncertainty as to how they might do so, and what it may mean for their schools' survival weighed heavily on the school leaders surveyed.

\section{HEALTH AND SAFETY CONCERNS}

A second major concern expressed by school leaders was their fears about health and safety of staff and students when schools began to reopen. Many discussed the fact that there was "no vaccine yet for the disease," expressing that in general "the reopening of the economy could produce an increasing number of [new people] infected with the novel coronavirus." This raised diverse concerns regarding how school leaders and the school community "may handle the aftermath of coming back to school." A large number of school leaders believed that "most of the parents will fear releasing their children to school amidst this pandemic." As one Dominican school leader commented, "I pray to God that this will end soon, but parents are also afraid to send their kids back to school. Some prefer to keep them at home and continue with remote learning."

Many participants in this study expressed deep concern "about protecting the staff and students from the virus while at school" and "that our staff and students could spread the virus," to each other. A few even expressed concern about their own health with a Guatemalan school proprietor saying, "I am diabetic and have not gone to school because I am at a greater risk of getting COVID-19. I have a great team and they are helping me manage the school." These concerns were voiced across the nations surveyed, with some leaders describing the precautions they are taking or will have to take to protect themselves, staff, and students, indicating the challenges these pose for school continuity and learning.

\section{Safety Measures for Reopening Schools}

School leaders discussed all the new safety measures they would need to put in place before schools can open, including securing "PPE for school children and staff." They were not at all sure "how to acquire masks for all students as classes resume." Many also discussed the importance of social distancing and the many challenges they would face. A Rwandan proprietor stated, "I am concerned about the spaces I have in the school. The new regulations from the Ministry of Education could affect the normal flow of the school." A few proprietors were worried that the school's physical building would probably not meet new government regulations regarding health and safety with "government restrictions being too strong" and wonder "what the conditions will be in terms of infrastructure, studentteacher ratio, and teacher turnover." A few mentioned that "The government promised to give some materials for this, but we are not sure we will have these materials" in time for schools to prepare accordingly.

There was also considerable concern about not having "health protocols" in place and the need to teach students (and staff) about "the necessary safety conditions." School leaders made the following comments about their limitations, noting that they did not have: "enough hand washing stations for all students," "classroom social distancing arrangement[s]," and that their "classrooms are too small and we need expansion." Public transport was also mentioned as a potential concern, as a proprietor noted, "What concerns us the most during this pandemic is that a child might get infected in the school bus."

Several school leaders shared health and safety-related ideas they were considering for when schools reopen. Many of these ideas were related to class scheduling to space out students, such as "...utilizing every Saturday for class and study," creating "...morning and evening sessions," or "...running a shift system to reduce the number of students in the classroom." As one Liberian school leader commented, whichever option chosen will likely require teachers "...to work extra time and to do many extra things." Given the financial constraints many proprietors were under, it is unlikely that they would be able to pay teachers for this additional workload raising additional concerns regarding staff burnout.

\section{Uncertainty}

Overall, school leaders expressed much uncertainty as to when schools would resume since some governments had not yet made any announcements at the time the survey was conducted. One Liberian school leader's comment was typical, "We are concerned about the beginning of the school year. We are not sure we can start in August." A small minority believed that "The school will run as normal." However, the vast majority of school leaders are "worried whether we can actually have normal classes where children would be able to interact freely in the class and school campus even if the situation improves." A few school leaders were "... concerned about how we are going to assess students' emotional and academic performance after this 
pandemic ends." As a Liberian school leader stated that because "students have a long period out of school, we can anticipate behavioral challenges when schools reopen.” And there was also concern that there would be a "... lack of motivation for students, due to repetition in their respective classes." As one Ghanaian leader noted, to address this concern, they are considering how they might "change the way we teach because we know that they have been locked in for so long, and we do not want them to feel the same way when they come back to school." Given that for many of the countries included in the study, the school year has begun, further research is needed to see how these concerns played out.

\section{LOSS OF STUDENT LEARNING AND DROPPING OUT}

The third major area of concern for school leaders in all nations surveyed was that children would be falling behind in their learning and possibly dropping out of school altogether. These concerns, in a few cases, led to novel approaches to the learning challenges faced by schools which are included below.

\section{Maintaining the Quality of Education: "Will Students Have a Quality Education?"}

School leaders from all countries commented that they were concerned with maintaining the quality of education and students' academic achievement both during the pandemic and when schools re-open for in-person classes. As one Dominican school leader commented, "My greatest concern is how to keep the children engaged in their studies so that there are no learning gaps or they did not lose interest in their study because of the long school closures." For many, this concern arose from the unequal access to education students have experienced. As a Peruvian school leader commented, "About $10 \%$ of students have not followed along with the learning process, they have not dropped out but are disconnected." This situation raised concerns for how to "level up students who are not engaged right now or are not connecting using technology."

While government programs were offered in some countries, including educational TV/Radio programming, school leaders commented that they did not reach all communities and did not serve everyone's needs. In one context, "only $60 \%$ of our students have a TV to watch the programs from the government, and the rest cannot. This is the reason why we have provided paperbased study guides." One Ugandan school leader commented, "Even though we tried to follow up on the educational TV programs from the government, it did not meet our standards." In Northeast India, for example, the government only provided educational programming in Mayuri, a language that is not spoken by a large number of the students that some schools serve.

School leaders shared concerns that younger students had been more difficult to support at a distance. A Guatemalan proprietor noted, "A large percentage of the students in this school are between 3 and 8 years old. It is very difficult to teach such young children and parents know this." School leaders commented that it requires considerable parental support at home in order for online education to be most effective. However, this raised additional challenges as one leader mentioned, "Though we give out assignments through WhatsApp, I know there are many parents who are not able to help their children with their assignments at home." A Guatemalan school proprietor noted a similar concern, commenting, "Our population is based in the city dump, most parents are illiterate and cannot manage even reading some of the guides to their kids, even though they want to."

Given that not all governments had implemented clear guidelines in terms of promotion during the pandemic, some school leaders expressed concerns that "students may lose the whole year" or be unable to advance given the lack of preparation and administration of key exams. This anxiety regarding exam results was echoed by many other school leaders, as students did not "see many subjects, and we do not know if the school year will stand." Some leaders believed that some families may even be banking on the idea of social promotion for all students commenting that "this is because they do not have money to pay tuition." Overall, school promotion and exams were seen as areas where there was considerable uncertainty over what steps governments and schools should take.

\section{Limited Access to Technology: "Parents Do Not Have Smartphones"}

A key issue raised by school leaders is related to student learning loss. Many of their students did not have access to the technology or internet needed in order to successfully employ certain distance learning strategies. As one Ghanaian proprietor commented, "Parents of children in the area we are located do not have complete access to technology. It is difficult to reach our goals this way. But we know that it is imperative to work in digital platforms for the new normal." As this comment illustrated, equity in access was raised as a key issue.

As one Rwandan school leader noted, "We could reach out to only $60-70 \%$ of our students through our current interventions [through] WhatsApp assignments"' lamenting that "I am not sure how to reach out to students in remote villages and those not using WhatsApp." This was echoed by a Rwandan school leader who said that their WhatsApp assignments only reached " $30 \%$ of our students [leaving a] larger number left out.” As one Liberian school leader commented, "... in this time of a pandemic when people struggle for food, to purchase a smartphone is another burden." Moreover, a family having access to technology does not always imply that students can use it; as one Rwandan leader mentioned, the "... mobile is always with their parents," and they may have been at work or need it for other activities.

For those students who did not have access to regular technology or Wi-Fi, school leaders commented on a variety of strategies they utilized to provide continuous learning opportunities. These included "Parents picking up textbooks and assignments from school and returning them when completed" and exercises being sent to children who "... are required to do it in their exercise books and then send pictures to their teachers." Proprietors and teachers had also taken steps such as preparing "...take home study material for their students on a 
weekly basis," "typing class notes and converting into PDFs" to send to parents, or even "sending home homework and materials by moto-taxis." By relying heavily on WhatsApp, school leaders can make learning accessible to "...parents that do not have Wi$\mathrm{Fi}$, but can afford $\$ 1$ internet for 3 days." Lack of internet access by teachers was also identified as a challenge. In one instance noted, a proprietor actually provided internet data to his teachers to support them in connecting with students via WhatsApp. As these examples indicate, the NSSs survey respondents, engaged in a variety of diverse strategies to ensure educational continuity for their students at a distance-each with different levels of success.

\section{Technology Training Needs for Teachers and Families: "Teachers Need to Learn How to Use Technology"}

In parity with the need for access, teachers and families need to know how to use technology in order to promote meaningful learning. School leaders described numerous challenges they and/or teachers have faced with regard to using technology. One comment was illustrative of issues described by several other school leaders, "Reinforcing knowledge in the use of virtual platforms for teaching kids has been a real challenge. Our teachers were not ready for teaching this way... we need better instruction in this area." For example, "Our teachers' abilities to manage virtual classes is a real challenge for us, we need to reinforce their skills in this area. We are sure that learning how to use media will bring us to another level as professionals."

Overall, numerous school leaders recognized the need to offer blended learning, but a comment by one proprietor captures the sentiment of others, "Our teachers will need training in this period when schools are closed... We believe that online learning is the way to go, but the cost it incurs will be a challenge to some parents." The barriers to this implementation may also go beyond cost; as one school leader commented that "My school is in a rural area and we lack technology knowledge, skill, and awareness." School leaders posed ideas that they may consider implementing in the future including, "making video classes and paying the teachers per class or per video if a situation arises where I am not able to pay them regularly." Another noted that they planned to "refurbish their computer lab to scale up online learning." As school closures extended in many countries with the prolongation of the pandemic, further research is needed to understand the implementation and efficacy of these efforts.

\section{NOVEL APPROACHES}

There were numerous examples of novel approaches being used by particular schools. Here we highlight three that may be helpful to other non-state schools or for NGOs working with them.

One school in Ethiopia sent a flash drive containing teachermade videos and other materials to each student's home. The student was then able to do his/her lesson and homework. The flash drive and any paperwork were returned to the school for the teacher to review; thus, no internet access was needed. In Ghana, one school owner reached out to families and students via WhatsApp. The school negotiated with parents to contribute 50
Cedis ( USD \$8.7) a month to pay the teacher's salary, so s/he could use WhatsApp to assist students in continuing to learn. Finally, one school owner in Northeast India explained that he was working with his team on a 1:4 concept wherein one teacher reaches out to four students in a particular locality. S/he taught the small group of students in-person 1-2 h daily. This school was charging a minimum fee to parents for this service.

\section{DISCUSSION}

We begin by discussing the major concerns of school leaders. This is followed by a discussion of the status of teachers, and then we describe the types of support teachers and school leaders provided to students and families. This section concludes with a brief discussion about other concerns that emerged in the study.

\section{School Leaders' Concerns}

Three major areas of concern were voiced by school leaders which included: the health and safety challenges of reopening schools, the school's financial sustainability, and student learning loss. School leaders were worried about not having safety measures to reopen schools as well as uncertainly as to when schools would reopen. Throughout the time of data collection and well into 2020 the LICs and MICs in this study did not provide financial support to NSSs to assist in their reopening nor were detailed reopening guidelines provided.

As for-profit social enterprises, NSSs receive little or no funding from the government yet, as noted earlier, they enroll large percentages of children. Clearly, if these schools are to succeed in their social mission, the government must recognize their unique needs by creating educational policies valuing the roles they play in helping to achieve educational equity. Most countries require private schools to be registered, but beyond this, they are too often neglected when it comes to professional development opportunities and the enforcement of regulation standards. As Barnett (2018) when he discussed the continuum of systems addressing school leadership and development, the majority of nations that are LICs and MICs have looselyregulated systems. This lack of support and regulation is even more prominent in NSSs.

\section{The Status of Teachers}

Across all 232 schools offering educational services during school closures, there was considerable variation from country to country, as well as within each nation, as to whether teachers were being fully or partially paid, or not at all; and if they continued to work or not. It is highly unreasonable, and a poor business practice, to expect staff to continue teaching with the promise they may get paid in the future. Financial stability is key to non-state schools; without it, teacher turnover will continue to be a major problem in LICs and MICs as schools reopen. Prior to the pandemic these nations already had major teaching shortages (UNESCO Institute for Statistics, 2016). Thus, it is crucial for NSSs to create financial sustainability plans that include operating budget reserves for emergencies such as pandemics, natural disasters, or other school disruptions. INGO's can be instrumental in supporting these efforts by providing 
training oriented to school leaders' creating or strengthening sustainable income generating practices.

\section{Educational Supports Provided by Teachers}

Across those schools offering educational services providing support, using paper-based materials was the most prevalent method followed by the use of technology such as messaging applications. Lack of access to technology devices and unreliable internet connectivity were noted as major challenges for teachers in providing equitable and quality instruction to students. This included not only children and families not having devices and/or internet connectivity but also teachers. As some school leaders noted, there was insufficient access to technology devices in the students' and teachers' homes, with many of the teachers reaching less than half of their students and families. In addition, the families that have access to technology devices and internet connectivity are often connected only through parents' smartphones with limited data plans paid for as needed. This means that device access in the home does not always result in children using the devices or accessing the internet for their education. This raises issues related to learning loss and school drop-out. As schools in many of the countries surveyed have continued to be closed for months, the impact on individual children and their families may be devastating. The World Bank predicts that for each child who is not able to continue to learn during school closures, the value loss in earnings is globally $\$ 16,000$ per child over the course of his/her lifetime (World Bank, 2020).

Connectivity and internet access were also raised as a limitation for school staff, with some school leaders taking it into their own hands to purchase data for staff. These findings reflect various points where NGOs and governments assistance can be instrumental in supporting schools in purchasing and updating the technological infrastructure both in schools and in homes. It would be useful to explore, by country and region within a nation, what percentage of homes have internet access, smartphones, and other devices. It is also relevant to consider that scaling up access and technology use among schools should be done while taking into account the diverse starting points and current technology use in a country. For example, schools in Peru, the Dominican Republic, and Guatemala reflected a greater use of technology overall with a strong presence of messaging apps, Video/Audio Conferencing, and LMS interventions in schools. On the other hand, African countries reflected a larger presence of paper use and follow-up after TV/Radio programming. As governments and NGOs plan for how best to support schools in each country, understanding the connectivity and technology use within schools and households will help set ambitious yet attainable goals for future growth.

When asked about how the schools were providing educational support, many respondents reported they, or teachers, were "Calling families to talk with parents and students every 1-2 weeks." However, from the data we cannot discern the exact purpose of those calls. School leaders and teachers may have been checking in to see how the child was doing in general vs. checking on specific academic issues. In addition, some school leaders did indicate they had called to pray with families. Therefore, these calls may or may not have represented direct support for learning. However, we know from the research literature (Epstein, 2018) that two-way communication between the school and the home is vital to a student's academic success. Therefore, even if the purpose is not to facilitate educational learning opportunities, school staff reaching out regarding the well-being of the children and/or families should be encouraged.

\section{OTHER CONCERNS}

In addition to what was found in the survey, it is also important to note what we did not find. There was no reference to the use of any type of books-textbooks or reading books. Many of the schools in this study lack resources such as books for students to take home. Accessing books is crucial to student learning. "While textbooks are only one-factor influencing student learning outcomes, their unavailability deprives students of an additional learning resource and of the opportunity to improve their reading habits (Fredriksen et al., 2015, p. ix)." There could be many reasons why school leaders did not reference books; however, in the African nations included in this study, readers are scarce or non-existent in schools. Nor was any mention made of e-books. If families do not have smartphones, they are unable to download free children's books and read to their children. Even though the NGOs staff had encouraged school leaders to inform parents about the availability of free reading books for download, such as those offered by Worldreader (Wise, 2020), prior to school closure, they were not referenced by respondents in this study. Also, use of these technologies requires that parents can read, and can read in English, French, or Spanish or the other languages in which those books are written.

Additionally, there is an absence of reading books in most of the respondents' schools. Textbooks of any type are rarely found in many elementary school classrooms and are even, at times, scarce in some junior-high school/middle school grades, with students often sharing textbooks (Brion and Cordeiro, 2020). If these schools had either libraries or reading centers in the lower grades, then schools could encourage families to borrow reading books. Unfortunately, far too many schools in SubSaharan Africa do not have school libraries, or reading centers in classrooms.

Finally, only brief mention was made by respondents to the socio-emotional support that teachers, administrators, children, and families will need as schools reopen. Stress, tension, isolation, and anxiety will create additional challenges which school leaders need to be prepared to manage.

\section{IMPLICATIONS AND RECOMMENDATIONS}

This study has numerous implications for the school leaders, their NGO partners and for the governments of LICs and MICs. Here we include five recommendations.

As schools begin to prepare for re-opening and the provision of in-person classes, NGOs can support schools in learning about 
and enacting essential back-to-school health and safety protocols, particularly in those countries that have not yet developed them. Some international organizations and national governments have created guidelines to support schools in developing plans and protocols to reduce the risk of exposure to COVID-19 upon returning to school. However, the amount of information can be overwhelming and time-consuming to digest and, therefore, counterproductive to effectively supporting school leaders during this transition. Thus, distilling this information as one education INGO has done for their partner schools, might prove helpful (Opportunity International, 2020).

School leaders discussed the numerous challenges they face in ensuring their schools' financial sustainability during the pandemic and upon return to in-person classes. Many of these challenges are connected to an inability to secure school payment from parents who are paying late, not paying at all, or expecting considerable discounts. Many schools are experiencing declining enrollments, while others predict that parents will not send children back when schools reopen due to financial and health-related concerns. These payment issues have generated considerable barriers in ability to pay teachers. Lack of school fee payments have also resulted in school leaders defaulting on loan payments with some even fearing loss of their establishments as they are unable to pay rent. As a result, our second recommendation is that NSSs need to consider developing various budget scenarios and contingency plans, coupled with support from NGOs offering financial sustainability coaching and training.

A third recommendation involves the use of blended learning. The global health crisis has made clear that schools need to be better prepared to provide education during disruptions that prevent students from being physically present in the classroom. The majority of the schools in this study were unprepared for school closures, especially for an extended period of time. Various hybrid learning models offer schools the opportunity to rely more heavily on the use of digital and online learning tools when students are not able to learn face to face. The schools in this study that had already implemented a blended learning strategy prior to the onset of the pandemic were better equipped to offer quality education during the disruption caused by COVID-19.

Interest in blended learning has surged in 2020 as schools have recognized that improving blended learning needs to be a present rather than distant goal. Now that a larger number of school leaders became familiar with using digital technology during most of 2020, it is an opportune time for making progress on the important role digital technology must play in teacher and student learning. Thus, in order for schools to be prepared for future disruptions to education, they must develop plans for how to effectively deliver education remotely. Since the extent of the hardware available locally as well as internet connectivity will vary by country, and regions within countries, school leaders need to understand their local contexts in developing plans. If the UNICEF 2020 report estimates for various regions of the world are accurate, the development of a plan for remote learning in a LIC such as Burkina Faso will differ substantially from a higher income nation such as Peru. For example, in Burkina Faso teachers using an analog, asynchronous approach of using print-based materials coupled with phone contact may be the most appropriate way to reach learners remotely, while in a country such as Peru, preparing for a digital synchronous model of remote learning by using a LMS would be more appropriate. NGOs working with schools can support them in assisting in the development of their remote learning plans.

A fourth recommendation involves teacher training. We know that teachers are key to any successful technology integration. Before schools purchase devices for students, school leaders must ensure that all teachers have easy access to the devices in order to facilitate their learning. They need training in how to use the device, and to experiment with it as they adapt and create lessons. Many of the teachers in this study did not have smart phones or home internet connectivity. To be prepared for future school closures, schools need to ensure teachers have access to phones and/or other mobile devices with internet access. NGOs can assist school leaders in how best to train teachers, identify what digital technologies are most appropriate for their environment and the best ways to ensure internet connectivity.

Finally, the type of digital tools used should depend on the context and the answers to the questions that World Bank technology specialist Trucano (2014) asks. He calls for addressing five challenges: affordability (Can schools or parents afford them?); accessibility (Will they be locked in a computer room?); connectivity (Do you need to access the internet?); electricity (Is there reliable power?); and, usability (Is this device designed for this environment?). NGOs that work in the education technology space can assist schools and governments as they explore the most appropriate digital tools for their contexts.

EdTech solutions often provide helpful educational material but are often missing the ways for schools to curate and organize materials into pathways for different subjects (learning plans) that fit national requirements. Learning Management Systems (LMS) and tools that can enable schools to adapt, curate and eventually create education content are key. There are free or low-cost LMSs that NGOs and governments can promote. For example, just prior to the pandemic, Uganda and UNICEF rolled out Kolibri, a free and open-sourced educational technology platform (Ntabadde, 2019). Expanding such a platform within Uganda will be key to being better prepared in the future. Thus, NGOs can assist schools by helping them discover LMSs such as Kolibri and then providing training support for teachers in its use.

It is during times of crisis that creative solutions often emerge; however, schools and their partner NGOs will need to develop disciplined processes for carefully reviewing these potential solutions. These NSSs are small businesses and are heavily, if not completely, dependent on tuition and fees in order to remain viable. Their sustainability depends on children and families being offered a quality educational experience both when schools are open, and when closed due to educational interruptions.

\section{CONCLUSION}

According to UNESCO (2020), 706 million pupils lack internet access, which makes remote learning even more of a challenge 
during a crisis. At the same time UNESCO reports that the world needs more than 69 million new teachers (UNESCO, 2016b). INGOs and NGOs partnering with schools need to consider strengthening their support to schools not only to support them in retaining their workforce, but also to support teachers in improving their skills using digital pedagogy. The issue is most acute in LICs in Sub-Saharan Africa, where $42 \%$ of primary and secondary teachers are untrained (UNESCO Institute for Statistics, 2016). Keeping teachers by ensuring that schools have financial sustainability plans in place is key. Clearly, if NSSs around the world want to be prepared for future school closures, then having a pipeline of professional teachers who understand how to implement blended learning is vital to their survival and success. This study has illustrated that teachers are instrumental to any pedagogical strategies, whether they are paper-based or delivered digitally and thus supporting their development is key.

Unless governments work diligently and urgently to support all schools, whether they are state-operated or NSSs, nations will be unable to achieve the SDG goal of educational equity. Additionally, without bringing internet access and devices to households and community centers, education inequities will not only continue but widen. Improving internet access for students, whether they attend government or non-state schools, is paramount. Not addressing the infrastructure and systemic issues that prevent students from accessing the internet will continue to exacerbate learning loss. No matter how hard school

\section{REFERENCES}

Barnett, B. (2018). Principal Preparation and Development: Highly Regulated or Loosely structured? School Leader Concerns. Available online at: https:// globaledleadership.org/2018/04/11/principal-preparation-and-developmenthighly-regulated-or-loosely-structured/ (accessed July 27, 2020).

Beadie, N., and Tolley, K. (eds.). (2013). Chartered Schools: Two Hundred Years of Independent Academies in the United States. London: Routledge. doi: $10.4324 / 9780203951606$

Brion, C., and Cordeiro, P. (2020). Voices of ghanaian head-teachers working in low-fee private schools. Int. J. Educ. Reform. 29, 170-190. doi: $10.1177 / 1056787919885367$

Bush, T., and Oduro, G. K. T. (2006). New principals in Africa: preparation, induction, and practice. J. Educ. Adm. 44, 359-375. doi: 10.1108/09578230610676587

CapPlus (2017). Banking on Education. Retrieved from: http://capplus.org/ banking-education-demand-finance-low-cost-private-schools/ (accessed August 1, 2020).

Cetin, M., and Kinik, F., and Sehkar, F. (2016). Effects of Student Success through the Balanced Leadership Framework. Univ. J. Educ. Res. V4, 675-682. doi: $10.13189 /$ ujer.2016.040403

Cordeiro, P., and Spencer, J. (2015). A Study of Low-Fee Private School Leaders' Trainings in Ghana: Tema and Kumasi. A Status Report for Edify. San Diego, CA: SOLES Global Center, University of San Diego.

Cordeiro, P. A., and Brion, C. (2018). Women school leaders: entrepreneurs in low fee private schools in three West African Nations. Front. Educ. 2:67. doi: 10.3389/feduc.2017.00067

Cordeiro, P. A., and Cunningham, W. G. (2012). Educational Leadership: A Bridge to Improved Practice, 5th Edn. Needham Heights, MA: Pearson.

Day Ashley, L. C., Mcloughlin, C., Aslam, M., Engel, J., Wales, J., Rawal, S., et al. (2014). The Role and Impact of Private Schools in Developing Countries: A Rigorous Review of the Evidence. London: Department for International Development. leaders try, they are part of a larger ecosystem and working alone they cannot effectively address educational inequities.

\section{DATA AVAILABILITY STATEMENT}

The raw data supporting the conclusions of this article will be made available by the authors, without undue reservation.

\section{ETHICS STATEMENT}

Ethical approval was not provided for this study on human participants because the data upon which this study is drawn was approved by the NGO as well as informed consent was received from participants. The patients/participants provided their written informed consent to participate in this study.

\section{AUTHOR CONTRIBUTIONS}

All authors listed have made a substantial, direct and intellectual contribution to the work, and approved it for publication.

\section{ACKNOWLEDGMENTS}

We are grateful to the staff of Edify who were involved in the data collection and input into the survey design and the original data upon which this paper is based.

Donlevy, J. (2009). Economic deterioration and the new 'normal' for schools. Int. J. Instr. Media 36,135-138.

Eacott, S., and Asuga, G. N. (2014). School leadership preparation and development in Africa: a critical insight. Educ. Manag. Admin. Leaders. 42, 919-934. doi: 10.1177/1741143214523013

Edify (2020). Retrieved from: www.Edify.org (accessed October 5, 2020).

Edify Education Task Force (2020). Education Interrupted: Edify's Roadmap to Continuing Learning during the 2020 Pandemic. San Diego, CA: Edify Education Task Force. Available online at: https://www.edify.org/wp-content/ uploads/2020/10/ExecutiveSummary_EdInterrupted_090220_FINAL.pdf

Epstein, J. (2018). School, Family and Community Partnerships. New York, NY: Taylor \& Francis. doi: 10.4324/9780429494673

Flessa, J., Bramwell, D., Fernandez, M., and Weinstein, J. (2017). School leadership in Latin America 2000-2016. Educ. Manag. Adm. Leadersh. 46, 182-206. doi: $10.1177 / 1741143217717277$

Flessa, J., Bramwell, D., Fernandez, M., and Weinstein, J. (2018). School leadership in Latin America 2000-2016. Educ. Manag. Admin. Leaders. 46, 182-206. doi: $10.1177 / 174114321771727$

Fredriksen, B., Brar, S., and Trucano, M. (2015). Getting Textbooks to Every Child in Sub-Saharan Africa: Strategies for Addressing the High Cost and Low availability Problem. World Bank Group. Available online at: https://reliefweb.int/sites/ reliefweb.int/files/resources/9781464805400.pdf

Fullan, M., and Hargreaves, A. (1991). Working Together for Your School. Hawthorn, VIC: ACEA.

Grissom, J. A., Egalite, A. J., and Lindsay, C. A. (2021). How Principals Affect Students and Schools: A Systematic Synthesis of Two Decades of Research. New York, NY: Wallace Foundation.

Grissom, J. A., and Harrington, J. R. (2010). Investing in administrator efficacy: an examination of professional development as a tool for enhancing principal effectiveness. J. Educ. 116, 583-611. doi: 10.1086/653631

Hallinger, P., and Kulophas, D. (2020). The evolving knowledge base on leadership and teacher professional learning: a bibliometric analysis of the literature, 1960-2018. Prof. Dev. Educ. 46, 521-540. doi: 10.1080/19415257.2019.1623287 
Ingersoll, R. M. (2001). Teacher turnover and teacher shortages: An organizational analysis. Am. Educ. Res. J. 38, 499-534. doi: 10.3102/00028312038 003499

Jones, S. (2008). Religious Schooling in America: Private Education and Public Life. Santa Barbara, CA: Praeger.

Judge, S., Pucket, K., and Cabuk, B. (2004). Digital equity: new findings for the early childhood longitudinal study. J. Res. Technol. Educ. 36, 383-396. doi: 10.1080/15391523.2004.10782421

Leithwood, K., and Jantzi, D. (2008). Linking Leadership to Student Learning: The Contributions of Leader Efficacy. Educ. Admin. Q. 44, 496-528. doi: 10.1177/0013161X08321501

Leithwood, K., Louis, K., Anderson, S., and Wahlstrom, K. (2004). How Leadership Influences Student Learning. New York, NY: The Wallace Foundation.

Lumby, J., Crow, G., and Pashiardis, P. (2008). International Handbook on the Preparation and Development of School Leaders. New York, NY: Routledge. doi: $10.4324 / 9780203872239$

MacBeath, J., Swaffield, S., Oduro, G., and Bosu, R. (2010). "Developing leadership for learning in Ghana: opportunities and challenges," in International Congress for School Effectiveness and Improvement (Kuala Lumpur). Available online at: https://citeseerx.ist.psu.edu/viewdoc/download?doi=10.1.1.1050.7489\&rep= rep1\&type $=$ pdf

Marzano, R. J., Walters, T., and McNulty, B. A. (2005). School Leadership that Works. Alexandria, VA: ASCD.

Mestry, R. (2020). "Leadership preparation and development for principals in South African public schools," in Preparation and Development of School Leaders in Africa, eds Moorosi and Bush (London: Bloomsbury Academic), = 73-89. doi: $10.5040 / 9781350081178.0010$

Mestry, R., and Grobler, B. R. (2003). The training and development of principals in managing schools effectively. Educ. Change. 7, 126-146. doi: $10.10520 /$ EJC31664

Miller, R. J., Goddard, R. D., Kim, M., Jacob, R., Goddard, Y., and Schroeder, P. (2016). Randomized control trial assessing the impact of McRel's balanced leadership program on principals in rural Michigan Schools. Educ. Admin. Q. 52, 531-566. doi: 10.1177/0013161X16 651926

Moorosi, P., and Bush, T. (eds.). (2020). Preparation and Development of School Leaders in Africa. New York, NY: Bloomsbury Academic.

Normore, A. H., and Lahera, A. I. (2018). Crossing the Bridge of the Digital Divide: Educational Leadership for Social Justice. Charlotte, NC: Information Age Publishing.

Ntabadde, C. M. (2019). UNICEF and Government of Uganda Roll out Kolibri Platform. Available online at: https://www.unicef.org/uganda/stories/unicefand-government-uganda-roll-out-kolibri-platform (accessed September 10, 2020).

Oduro, G., and MacBeath, J. (2003). Traditions and tensions in leadership: the Ghanaian experience. Cambridge J. Educ. 33, 441-455. doi: 10.1080/0305764032000122050

Opportunity International (2020). COVID-19 response Toolkit. Available online at: https://edufinance.org/covid-19-response-toolkit/

Otunga, R., Serem, D. K., and Kindiki, J. N. (2008). "School leadership development in Africa," in International Handbook on the Preparation and Development of School Leaders, eds J. Lumby, G. Crow, and P. Pashiardis (New York, NY: Routledge), 367-382.

Schleicher, A. (2012). Preparing Teachers and Developing School Leaders for the 21st Century: Lessons from Around the World. Paris: OECD. doi: 10.1787/9789264174559-en

Serrajuddin, U., and Hamadeh, N. (2020). New World Bank Country Classifications by Income: $2020-2021$.

Sivasubramaniam, M., and Rider, S. (2017). "Faith-based low-fee private schools in Kenya and Haiti: The paradox of philanthropy and enterprise," in Religion and Education, eds M. Sivasubramaniam and R. Hayhoe (Oxford, UK: Symposium Books) 225-249.

Stelitano, Laura, Sy Doan, Woo, A., Diliberti, M., Kaufman, J. H., et al. (2020). The Digital Divide and COVID-19: Teachers' Perceptions of Inequities in Students' Internet Access and Participation in Remote Learning. Creative Commons
Attribution 4.0 International Public License, 2020. Available online at: https://www.rand.org/pubs/research_reports/RRA134-3.html (accessed March $21,2021)$.

Swaffield, S., Jull, S., and Ampah-Mensah, A. (2013). Using mobile phone texting to support the capacity of school leaders in Ghana to practise Leadership for Learning. Proc. Soc. Behav. Sci. 103, 1295-1302. doi: 10.1016/j.sbspro.2013.10.459

The Economist. (2015). Learning Unleashed: Low-Cost Private Schools. Available online at: https://www.economist.com/briefing/2015/08/01/learningunleashed

Tooley, J., and Dixon, P. (2007). Private schooling for low-income families: A census and comparative survey in East Delhi, India. Int. J. Educ. Dev. 27, 2005-219. doi: 10.1016/j.ijedudev.2006.08.002

Trucano, M. (2014). In Search of the Ideal Educational Technology Device for Developing Countries. Retrieved from: https://blogs.worldbank.org/team/ michael-trucano (accessed October 10, 2020).

UN Sustainable Development Goals (2015). Ensure inclusive and equitable quality education and promote lifelong learning opportunities for all. Available online at: https://sdgs.un.org/goals/goal4

UNESCO (2015). Education for All Global Monitoring Report. Policy Paper. Available online at: https://unesdoc.unesco.org/ark:/48223/pf0000233557 (accessed March 20, 2021).

UNESCO (2016a). Welcome to the United Nations, UN and Non-Governmental Organizations (NGOs): A Quick Guide. Retrieved from: https://research.un.org/ en/ngo (accessed November 15, 2020).

UNESCO (2016b). The World Needs Almost 69 Million New Teachers to Reach the 2030 Education Goals. Available online at: http://uis.unesco.org/en/document/ world-needs-almost-69-million-new-teachers-reach-2030-education-goals (accessed July 10, 2020).

UNESCO (2018). Concept note for the 2021 Global Education Monitoring Report on Non-state Actors. (UNESDOC Digital Library), p. 4.

UNESCO (2020). Retrieved from: https://www.un.org/millenniumgoals/ (accessed October 8, 2020).

UNESCO Institute for Statistics (2016). The World Needs Almost 60 Million New Teachers to Reach the 2030 Education Goals. Retrieved from: http://uis.unesco. $\mathrm{org} /$ sites/default/files/documents/fs39-the-world-needs-almost-69-millionnew-teachers-to-reach-the-2030-education-goals-2016-en.pdf (accessed July $10,2020)$.

United National Children's Fund and International Telecommunication Union (2020). How Many Children and Young People Have Internet Access at Home? Estimating Digital Connectivity During the COVID-19 Pandemic. New York, NY: UNICEF.

Wise, M. (2020). Bringing Free eBooks to Students in Africa During the Covid19 Pandemic. Retrieved from: https://www.worldreader.org/blog/bringingfree-ebooks-to-students-in-africa-during-the-covid-19-pandemic/ (accessed August 19, 2020).

Woden, Q. T. (2014). Faith-Inspired Schools in Sub-Saharan Africa: An Introduction to the Summer 2014 Issue. Rev. Faith Int. Aff. 12, 1-4. doi: $10.1080 / 15570274.2014 .918754$

World Bank (2020). "COVID-19 Could Lead to Permanent Loss in Learning and Trillions of Dollars in Lost Earnings." Available online at: https://www. worldbank.org/en/news/press-release/2020/06/18/covid-19-could-lead-topermanent-loss-in-learning-and-trillions-of-dollars-in-lost-earnings

Conflict of Interest: The authors declare that the research was conducted in the absence of any commercial or financial relationships that could be construed as a potential conflict of interest.

Copyright $\odot 2021$ Cordeiro, Gluckman and Johnson. This is an open-access article distributed under the terms of the Creative Commons Attribution License (CC BY). The use, distribution or reproduction in other forums is permitted, provided the original author(s) and the copyright owner(s) are credited and that the original publication in this journal is cited, in accordance with accepted academic practice. No use, distribution or reproduction is permitted which does not comply with these terms. 